\title{
6. Skills mobility and postsecondary education in the ASEAN Economic Community
}

\section{Maki Kato}

\section{INTRODUCTION}

Understanding the structure, causes, and impact of high-skilled intraregional labor mobility is an important precursor to building migration policy. Intra-ASEAN mobility has increased in recent years. In 2013, for example, $70 \%$ of the 9.5 million migrants living in ASEAN countries came from other ASEAN countries, far above the 40\% in 1990 (Papademetriou et al. 2016). However, the intra-ASEAN migrant profile is incomplete because of the absence of sufficient, adequate, and appropriate data. Yet, despite these data obstacles, two intra-ASEAN migration characteristics are clear: (i) low-skilled workers comprise the majority of migrants; and (ii) the concentration of migration flows occur over a few main bilateral corridors. There is little available evidence as to whether these characteristics are ASEAN-specific or shared with other economic or trade communities. Therefore, this chapter tries to clarify ASEAN's migration characteristics by comparing these characteristics with other economic communities.

The analysis uses a high-skilled migration dataset with non-Organisation for Economic Co-operation and Development (non-OECD) countries as migrant hosts. Several comprehensive datasets of source/host migrations are available (Özden et al. 2011; Docquier and Marfouk 2004, 2006). However, only the latest from Artuc et al. (2015) - which includes nonOECD hosts and educational levels-is sufficient for the analysis here, even though it includes only two time points (1990 and 2000). While Asian countries such as India and the People's Republic of China (PRC) were included in the analysis, ASEAN was not.

After exploring the basic features of ASEAN migration, this chapter investigates the relationships between high-skilled labor migration (high-skill migration) and people (human capital) with postsecondary education. Considering the commonalities between mobility and human 
capital development, the chapter examines (i) the role of human capital stock as determinants of migration and (ii) the impact of migration on postsecondary-educated human capital stock. International migration and education share common factors, as both invest in human agents whose decisions are intertwined in many dimensions (Dustmann and Glitz 2011). For instance, wage differences are the main drivers of both migration and education. From the perspective of capabilities proposed by Sen (1999), de Haas (2009) pointed out the general mechanism by which migration and human development are interrelated, the necessity of human development for migration, and the potential of migration for well-being and enhancing freedom. It is thus appropriate to discuss the cause and impact of highskill migration together with postsecondary education.

As described in the literature review below, previous studies investigated these relationships empirically. But there is room for improvement. Few studies analyzed the ASEAN situation with a focus on intraregional mobility. The estimation model can be improved to consider the scope of effect and heterogeneity of countries and regions. Although the discussion of migration effects usually focuses on source countries, this chapter covers both source and host countries because migrants generate significant impacts on the native populations of host countries by participating in local capital and labor markets, as shown by Borjas (1994). Both source and host countries could have positive and negative impacts on various aspects - such as human capital, labor markets, and science and technology (Cervantes and Guellec 2002) — while several empirical studies show inconclusive results (Dustmann and Glitz 2011).

The definition of high-skill migration is complex. For instance, Papademetriou et al. (2016) define high-skill workers as individuals with a university education or equivalent professional experience. ASEAN members target high-skill migrants in eight professions-engineering, nursing, architecture, medicine, dentistry, tourism, surveying, and accounting. Considering the currently ambiguous definition-and viewed from a macro-perspective - this chapter defines high-skill individuals as those with postsecondary education and low-skill individuals as generally less educated. The definition of migration follows the one in the dataset provided by Artuc et al. (2015), where migration is measured on the country of birth as opposed to citizenship, which can change over time.

Thus, this chapter aims to clarify how high-skill migration is related to postsecondary education within ASEAN by comparing the relationship with other regional communities. Artuc et al.'s dataset for 1990 and 2000 is used for empirical analysis and estimation. The results show that intra-ASEAN migration was responsible for the lowest proportion of high-skill migration and the second-highest concentration of bilateral corridors among the four 
regional communities examined-ASEAN, the Mercado Común del Sur (Common Market of the South, or MERCOSUR), the North American Free Trade Agreement (NAFTA), and the European Union (EU). High-skill intra-ASEAN migration is explained by the postsecondary-educated human capital stock in the source country, but not in the host country. However, bilateral high-skill intra-ASEAN mobility explains the postsecondaryeducated human capital stock in both source and host countries. Therefore, high-skill ASEAN mobility could have a positive relationship with an increase in postsecondary education investment in source countries. These results indicate a need to encourage high-skill intra-ASEAN migration because of its positive effect on postsecondary education.

Section 2 describes the relevant literature and introduces research questions. Section 3 explains the model and dataset. Section 4 summarizes the results, and Section 5 concludes.

\section{LITERATURE REVIEW AND RESEARCH QUESTIONS}

High-skill migration, but not migration itself, has increased rapidly worldwide. In 2010, the 214 million international migrants represented only $3 \%$ of the world population, and increased only modestly compared with the accelerating global population growth (King 2012). The increase in the migration rate was just 0.4 of a percentage point from 1960 to 2005 (2.5-2.9\% of the population) compared with trade, which increased threefold over the same period. However, high-skill migration shows a different picture. High-skill migrants to OECD countries increased at the same rate as trade (Docquier and Rapoport 2012). Following these trends, Clemens et al. (2014) show that the number of studies about migration and development grew sharply, and the topic has emerged as a proper research subfield. Most past studies focused on single hosts in the wealthiest nations (Kim and Cohen 2010); however, the improved Artuc et al. (2015) dataset made possible research targeting multiple hosts, including non-OECD countries.

Several reports and papers discuss high-skill migration in ASEAN countries (most published recently) and attempt to provide policy recommendations. As mentioned, these studies show that low-skill workers comprise the majority of migrants - in 2007, low-skill workers comprised $87 \%$ of intra-ASEAN migrants and $73 \%$ of global migrants (Orbeta 2013). They also show that migration flows concentrate within a few main bilateral corridors. Based on United Nations data from 2013, the top five corridors (from 57 intra-ASEAN corridors) represent around $88 \%$ of the total (Sugiyarto and Agunias 2014). 
Comparisons with other economic communities are useful. Jurje and Lavenex (2015) compared mobility commitments in trade agreements to explore the labor mobility model in ASEAN countries with those of MERCOSUR, NAFTA, and the EU. While they used interview and documentary survey data to discuss the prospects for deeper labor market cooperation-including service-related mobility-additional empirical analysis on high-skill migration in ASEAN countries would help; even though simple data comparisons are insufficient considering the various historical, cultural, and socioeconomic backgrounds of the regional communities. Mobility policies or commitments, especially in host countries, also influence decisions to migrate. This leads to the first research question:

Research question 1 Are the high-skill intra-ASEAN migration characteristics - of (i) fewer high-skill migrants than low-skill migrants and (ii) migration concentrated in just a few main corridors - shared by other regional communities?

Although no single theory captures the complexity of migration, several theories of the determinants of migration have developed over the last 50 years (King 2012). One is the push-and-pull theory, where push factors describe migration from a source country or region because of poverty, political repression, or income level, and migration driven by pull factors such as better income or job opportunities in the host country. Piore (1979) found that migration was primarily driven by pull rather than push factors. The push-and-pull theory was followed by a neoclassical theory based on utility maximization; and then by a network theory, which moved beyond previous impersonal theories and connected individual and sociocultural reasons for migrating (Faist 1997). However, pull factors - such as wage differences between regions - remain crucial in driving migration (Mayda 2010; Clark et al. 2007; Grogger and Hanson 2011).

High-skill workers tend to migrate to OECD countries. In 2000, 72.6\% of the 28.8 million high-skill workers worldwide migrated to OECD countries, while $46.1 \%$ of the 83.1 million low-skill workers globally migrated to the same countries (Artuc et al. 2015). Asian migrants followed these trends (ADBI 2014). Wage differentials and the accumulation of human capital (knowledge and experience) make OECD countries attractive. In theory, the neoclassical growth model predicts a human capital flow from abundant to scarce regions. But more evident in practice is the "brain drain" from scarce to abundant regions (Lucas 1988).

Using United States (US) data, Moretti (2013) empirically showed that postsecondary-educated workers move to regions with a greater accumulation of human capital. This could be because postsecondary-educated 
people are more mobile as they seek distant educational or market opportunities (Wozniak 2010). While derived from domestic migration in the US, the argument might extend to international migration. This leads to the second research question:

Research question 2 Does high-skill intra-ASEAN migration positively relate to postsecondary-educated human capital in both source and host countries?

The impact of migration, especially on source countries, has been the main theme for much of the literature. However, the impact of international migration on human capital investment remains inconclusive. ${ }^{1}$ Concerning the "beneficial brain drain" (Mountford 1997), some studies point to a remittance effect (Rapoport and Docquier 2006; Yang 2008) and prospects of better job opportunities abroad (Stark et al. 1997) as reasons to invest in further education. This has gained popularity recently after a series of macro-empirical studies by Beine et al. (2001, 2008, and 2010). The positive country-level impact was confirmed empirically in Cape Verde (Batista et al. 2012), Tonga and Papua New Guinea (Gibson and McKenzie 2011), and Africa (Easterly and Nyarko 2009) - although the first two studies covered sparsely populated island states with a heavy migration impact. However, several studies question the effect of "brain gain" through brain drain. For instance, based on partial and general equilibrium models, Schiff (2005) concluded that the brain gain actually resulted in smaller human capital gains and had a negative impact on human capital stock. Empirical analyses by Lucas (2007) and Checchi et al. (2007) had similar results.

Considering the inclusiveness of the effect of migration on human capital development, heterogeneity is assumed to be related. Reviewing migration and development literature from a theoretical perspective, de Haas (2010) concluded the picture was more nuanced. In some cases, migration has a positive effect, but in others there is no effect, or even a negative effect. Bhagwati (2009) described the diversity of impacts on source countries based on their level of human capital. These contradictory empirical results show that migration rarely has a uniform impact - the brain drain was massive only in small or very poor countries (de Haas 2010).

Heterogeneous determinants for enrollment in postsecondary education are another impact of migration. In addition to individual incentives, there are several other determinants for enrolling in postsecondary education. For example, in Japan these determinants include intertwined micro, mezzo, and macro student socioeconomic factors - such as household income, parent jobs and educational careers, university capacity in student home towns and education costs, job availability after graduation, and 
regional cultural and historical factors (Kato 2016). At the micro level, according to Eccles (1994, 2005), expectancy-value theory shows major career choices are directly influenced by the deeply intertwined factors of psychological ability, competence, and subjective task value. Thus, the decision for postsecondary education enrollment could depend on complex conditions where incentives only play a partial role. This chapter tries to analyze the impact of migration on postsecondary enrollment in ASEAN by comparing country or regional heterogeneity-giving rise to the third research question:

Research question 3 Does high-skill intra-ASEAN migration influence postsecondary education enrollment in both source and host countries?

\section{MODEL AND ESTIMATION METHOD}

The first research question on ASEAN skill levels and migration corridors can be analyzed using descriptive statistics and research, as described in the Section 5 results below. The second and third require estimation models, which are discussed here.

The first model estimates the relationship between high-skill intraASEAN migration and postsecondary-educated human capital (Model (6.1)).

For bilateral skill migration, the gravity model - widely used by recent international migration studies - is used because of better access to improved bilateral data (Ramos 2016). Previous empirical studies using the gravity model include those exploring the determinants of international mobility (Kim and Cohen 2010; Beine et al. 2014) and bilateral knowledge networks (Maggioni and Uberti 2009).

The gravity model views migration as directly proportional to a country's population size or income and inversely proportional to the physical distance between the two countries. The model takes account of some variables, including language, culture, and shared history-such as former colonial links (Mayda 2010). Beine et al. (2014) also identified a significant network effect and destination appeal — such as university quality in host countries and number of international students. This chapter refers to the model proposed by Beine et al. (2014) because of the similarity between study targets.

The model for bilateral skill migration is defined as follows:

Skillmigration $_{(\mathrm{i}, \mathrm{j}, \mathrm{t})}=\alpha_{0}+\alpha_{1}$ Relationship $_{(\mathrm{i}, \mathrm{j}, \mathrm{t})}+\alpha_{2}$ ODspecific $_{(\mathrm{i}, \mathrm{j}, \mathrm{t})}+\alpha_{3}$ $\operatorname{Regiondum}_{(\mathrm{i}, \mathrm{j})}+v_{(\mathrm{i}, \mathrm{j})}+\varepsilon_{(\mathrm{i}, \mathrm{j}, \mathrm{t})}$ 
where Skillmigration ${ }_{(\mathrm{i}, \mathrm{j}, \mathrm{t}}$ denotes the number of migrants from source country $i$ to host country $j(i \neq j)$ in time $t, v_{(\mathrm{i}, \mathrm{j})}$ shows the unobserved bilateral factors, $\varepsilon_{(\mathrm{i}, \mathrm{j}, \mathrm{t})} \sim \operatorname{IN}\left(0, \partial^{2}\right)$ is an error term, and $\alpha_{0}$ a constant. The relationships of bilateral countries are captured as Relationship $\mathrm{p}_{(\mathrm{i}, \mathrm{j}, \mathrm{t}) \text {, }}$ source- and host-country specific as ODspecific $\mathrm{i}_{(\mathrm{i}, \mathrm{j}, \mathrm{t}}$, and a regional dummy as Regiondum (i,j) $_{\text {. }}$.

These relationships include the distance and existing networks between the two countries. Although the analysis for developing countries shows that high-skill migration is less sensitive to geographic distance (Docquier and Rapoport 2012) - probably because of the development of transportation and communication technologies - it is worthwhile to investigate the impact of distance at the regional level. Beine et al. (2014) described the network as the total migration stock from the source country $i$ to host country $j$. However, in this chapter the network is substituted by trade due to data limitations.

Beine et al. (2014) also included only host-specific variables such as skill prices for the specific factors considered. However, the model used here includes both source- and host-specific variables, such as the impact of economic level. Concerning source-specific factors, data from 1990 to 2000 confirm that middle-income countries have the highest average rates of high-skill migration to OECD countries - because people in these highincome countries have less incentive to emigrate and people in low-income countries have liquidity constraints (Beine et al. 2007). Martin (1996) confirmed an inverted U-shaped relationship or hump hypothesis between high-skill migration and income. Given these differences, Relationship $(\mathrm{i}, \mathrm{j}, \mathrm{t})$, ODspecific $_{(\mathrm{i}, \mathrm{j}, \mathrm{t})}$, and Regiondum ${ }_{(\mathrm{i}, \mathrm{j})}$ in $\operatorname{Model}(6 . \mathrm{a})$ are replaced as follows:

$$
\begin{aligned}
& \operatorname{lnSkillmigration~}_{(\mathrm{i}, \mathrm{j}, \mathrm{t})}=\beta_{0}+\beta_{1} \ln \text { Dist }_{(\mathrm{i}, \mathrm{j})}+\beta_{2} \ln \text { Trade }_{(\mathrm{i}, \mathrm{j})}+\beta_{3} \text { Lang }_{(\mathrm{i}, \mathrm{j})} \\
& +\beta_{4} \operatorname{Col}_{(\mathrm{i}, \mathrm{j})}+\beta_{5} \operatorname{lnmax}\left\{\text { Income }_{(\mathrm{j}, \mathrm{t})}-\text { Income }_{(\mathrm{i}, \mathrm{t})}, 0\right\}+\beta_{6} \operatorname{lnmax}\left\{\text { Hcapital }_{(\mathrm{j}, \mathrm{t})}\right. \\
& \left.- \text { Hcapital }_{(\mathrm{i}, \mathrm{t})}, 0\right\}+\beta_{7} \ln _{\text {Income }_{(\mathrm{j}, \mathrm{t})}}+\beta_{8} \ln _{\text {Income }_{(\mathrm{i}, \mathrm{t}}}+\beta_{9} \ln \text { Hcapital }_{(\mathrm{j}, \mathrm{t})} \\
& +\beta_{10} \ln \text { Hcapital }_{(\mathrm{j}, \mathrm{t})}+\beta_{11} \text { Regiondum }_{(\mathrm{i}, \mathrm{j})}+v_{(\mathrm{i}, \mathrm{j})}+\varepsilon_{(\mathrm{i}, \mathrm{j}, \mathrm{t})}
\end{aligned}
$$

In replacing Relationship ${ }_{(\mathrm{i}, \mathrm{j}, \mathrm{t})}$, Dist $t_{(\mathrm{i}, \mathrm{j})}$, denotes physical distance and Trade $_{(\mathrm{i}, \mathrm{j}, \mathrm{t}}$, shows trade flows between the two countries. Language is captured as Lang $_{(\mathrm{i}, \mathrm{j})}$ and former colonial ties as $\mathrm{Col}_{(\mathrm{i}, \mathrm{j}, \mathrm{t})}$. Bilateral differences are denoted as $\left\{\right.$ Income $_{(\mathrm{j}, \mathrm{t})}-$ Income $\left._{(\mathrm{i}, \mathrm{t})}, 0\right\}$ for income differences and $\max \left\{\right.$ Hcapital $_{(\mathrm{j}, \mathrm{t})}-$ Hcapital $\left._{(\mathrm{i}, \mathrm{t},}, 0\right\}$ for human capital differences, which were modified to either take the greater value of the surplus of hosts or zero because the migration decision depends on the relative conditions of the paired countries. 


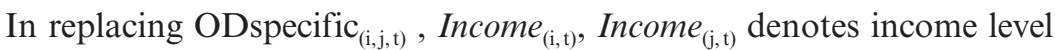
and denotes human capital level.

Regiondum $_{(\mathrm{i}, \mathrm{j})}$ shows the regional dummy, whether migration is intraregional within each of the four regional communities (1) or not (0).

In Model (6.1), the coefficient of most independent variables (from $\beta_{2}$ to $\left.\beta_{10}\right)$ are expected to be positive and significant. For Relationship $p_{(\mathrm{i}, \mathrm{j}, \mathrm{t}}$ they are Trade $_{(\mathrm{i}, \mathrm{j}, \mathrm{t}}, \operatorname{Lang}_{(\mathrm{i}, \mathrm{j}}, \operatorname{Col}_{(\mathrm{i}, \mathrm{j}}, \max \left\{\right.$ Income $_{(\mathrm{j}, \mathrm{t})}-$ Income $\left._{(\mathrm{i}, \mathrm{t})}, 0\right\}, \max \left\{\right.$ Hcapital $_{(\mathrm{i}, \mathrm{t})}$

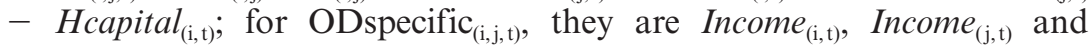
Hcapital $_{(\mathrm{i}, \mathrm{t},}$, Hcapital $_{(\mathrm{j}, \mathrm{t})}$, assuming a bigger flow is observed within the resource-rich countries. As usual, Dist $_{(\mathrm{i}, \mathrm{j})}\left(\beta_{1}\right)$ is expected to be negative and significant, and for Regiondum $\left(\mathrm{i}, \mathrm{j}, \mathrm{,},\left(\beta_{11}\right)\right.$ is expected to be significant in the case of regional differences in flows.

Nine models were used to conduct the estimation: the overall world migration flows, and intra- and out-migration flows from ASEAN, MERCOSUR, NAFTA, and the EU.

The second model-which deals with Research Question 3- estimates how high-skill intra-ASEAN migration influences postsecondary education enrollment (Model (6.2)). The model is assumed as a simple production function. Considering the two-way causal relationship between human capital stock and economic development (Kato and Ando 2007), income level is added as an independent variable with a relationship to postsecondary-educated human capital stock. Because this chapter assumes the effect of high-skill migration on source and host countries, the variables describing postsecondary-educated human capital stock, income level, and skill migration are treated as a product of those variables in source and host countries, or

$\ln \left(\Delta\right.$ Hcapital $_{(\mathrm{i})} * \Delta$ Hcapital $\left._{(\mathrm{j})}\right)=\beta_{0}+\beta_{1} \ln \left(\Delta\right.$ Skillmigration $_{(\mathrm{i})} *$ Skillmigration $\left._{(\mathrm{j})}\right)+\beta_{2} \ln \left(\Delta\right.$ Income $_{(\mathrm{i})} * \Delta$ Income $\left._{(\mathrm{j})}\right)+v_{(\mathrm{i}, \mathrm{j})}+\varepsilon_{(\mathrm{i}, \mathrm{j})}$

The coefficients of the independent variables in Model (6.2) $\left(\beta_{1}, \beta_{2}\right)$ are expected to be positive.

\subsection{Estimation Method}

One of the challenges in using the gravity model (Research Question 2) is how to deal with the potential presence of zero or negative values in the case of net or no change in migrant flows. While alternative count data models may be used-such as Poisson, negative binominal, and zeroinflated models (Ramos 2016) - a count data model is used with some identification tests to determine which distribution pattern works.

The dependent variable in Model (6.1) uses panel data; therefore, a panel 
estimation method can be applied, which assumes either fixed or random effects. The fixed effect is appropriate when the existence of a country- or corridor-specific effect is assumed. Alternatively, Hausman test results can decide whether the fixed or random effect is appropriate. However, due to a one-time point influential dummy such as distance, the random-effect model is used - as the fixed-effect model loses the one-time point data. One of the advantages of using panel data is that it is less likely to have multicollinearity problems, which could easily happen for Model (6.1) - because of the independent variables such as income and postsecondary-educated human capital stock. However, models using different combinations of independent variables were estimated to check for robustness. The ordinary least squares method was used in Model (6.2), which is based on the production function and where data time points are one.

\section{DATA}

Table 6.1 describes the data used. It merges four datasets with a variety of countries and various levels of data availability. The high-skill migration dataset from Artuc et al. (2015) initially included 195 countries, which was reduced here to 186 . The dataset provides the number of postsecondaryeducated bilateral migrant stock and direction of migration. It was the first to develop a global human capital migration map including non-OECD countries as hosts, which differs completely from previous studies that targeted high-skill migrant movement to OECD countries. The dataset used here found that non-OECD hosts account for one-third of high-skill migration worldwide, with a higher proportion of postsecondary-educated people immigrating to OECD countries.

\section{RESULTS}

\subsection{Characteristics of High-Skill Intra-ASEAN Migration (Research Question 1)}

\subsubsection{High-skill migration in regional communities}

Table 6.2 offers an overview of four regional communities-ASEAN, MERCOSUR, NAFTA, and the EU. ASEAN has the largest population yet the smallest economic output. Members with smaller populations and lower economic levels have a greater migration impact than those that are larger and higher income. In 2010, the average proportion of the ASEAN postsecondary-educated population ranked third-MERCOSUR had the 
Table 6.1 Data description and variable sources

\begin{tabular}{|c|c|c|}
\hline Variable name & Description & Source \\
\hline Skillmigration & $\begin{array}{l}\text { Number of postsecondary- } \\
\text { educated migrants and } \\
\text { direction of migration }\end{array}$ & $\begin{array}{l}\text { Comprehensive migration matrixes } \\
\text { by education level and gender } \\
\text { (1990-2000) } \\
\text { Database Version } 2 \text { (April 2013), } \\
\text { analyzed by Artuc et al. (2015) } \\
\text { (see http://perso.uclouvain.be/ } \\
\text { frederic.docquier/oxlight.htm) }\end{array}$ \\
\hline Income & $\begin{array}{l}\text { Per capita gross national } \\
\text { income based on } \\
\text { purchasing power parity } \\
\text { (in USD) }\end{array}$ & $\begin{array}{l}\text { World Bank World Development } \\
\text { Indicators } \\
\text { (see http://data.worldbank.org/ } \\
\text { products/wdi) }\end{array}$ \\
\hline Hcapital & $\begin{array}{l}\text { Postsecondary-educated } \\
\text { people aged } 15 \text { years and } \\
\text { over in } 2010\end{array}$ & $\begin{array}{l}\text { Barro-Lee Educational Attainment } \\
\text { Dataset } \\
\text { (see http://www.barrolee.com/) }\end{array}$ \\
\hline Dist & $\begin{array}{l}\text { Distance between two } \\
\text { countries based on } \\
\text { distance between their } \\
\text { largest cities, where } \\
\text { intercity distance is } \\
\text { weighted by city's share } \\
\text { of overall population }\end{array}$ & $\begin{array}{l}\text { Centre d'Etudes Prospectives et } \\
\text { d'Informations Internationales } \\
\text { (CEPII) data: dist-cepii } \\
\text { (see http://www.cepii.fr/) }\end{array}$ \\
\hline Trade & $\begin{array}{l}\text { Annual export and import } \\
\text { of goods between two } \\
\text { countries (in USD). } \\
\text { Data for } 1990 \text { are } \\
\text { unavailable at the } \\
\text { country level-1995 data } \\
\text { were substituted. }\end{array}$ & $\begin{array}{l}\text { United Nations Comtrade } \\
\text { Database } \\
\text { (see https://comtrade.un.org/) }\end{array}$ \\
\hline
\end{tabular}

Note: Data accessed 14 February 2017.

smallest enrollment ratio for postsecondary education. This could relate to the proportion of skilled workers among total migrants.

Table 6.3 shows the high-skill migration for the four regional communities in 1990 and 2000. The Herfindahl-Hirschman Index (HHI) - usually used to show market share - shows the concentration of bilateral migration corridors. ${ }^{2}$ ASEAN has some differences and commonalities with other regions. For instance, the number of high-skill intra-ASEAN migrants was less than out-migrants in 2000. The proportion of intraregional migrants to extra-regional migrants was 0.97 (ASEAN), 3.88 (MERCOSUR), 190.10 


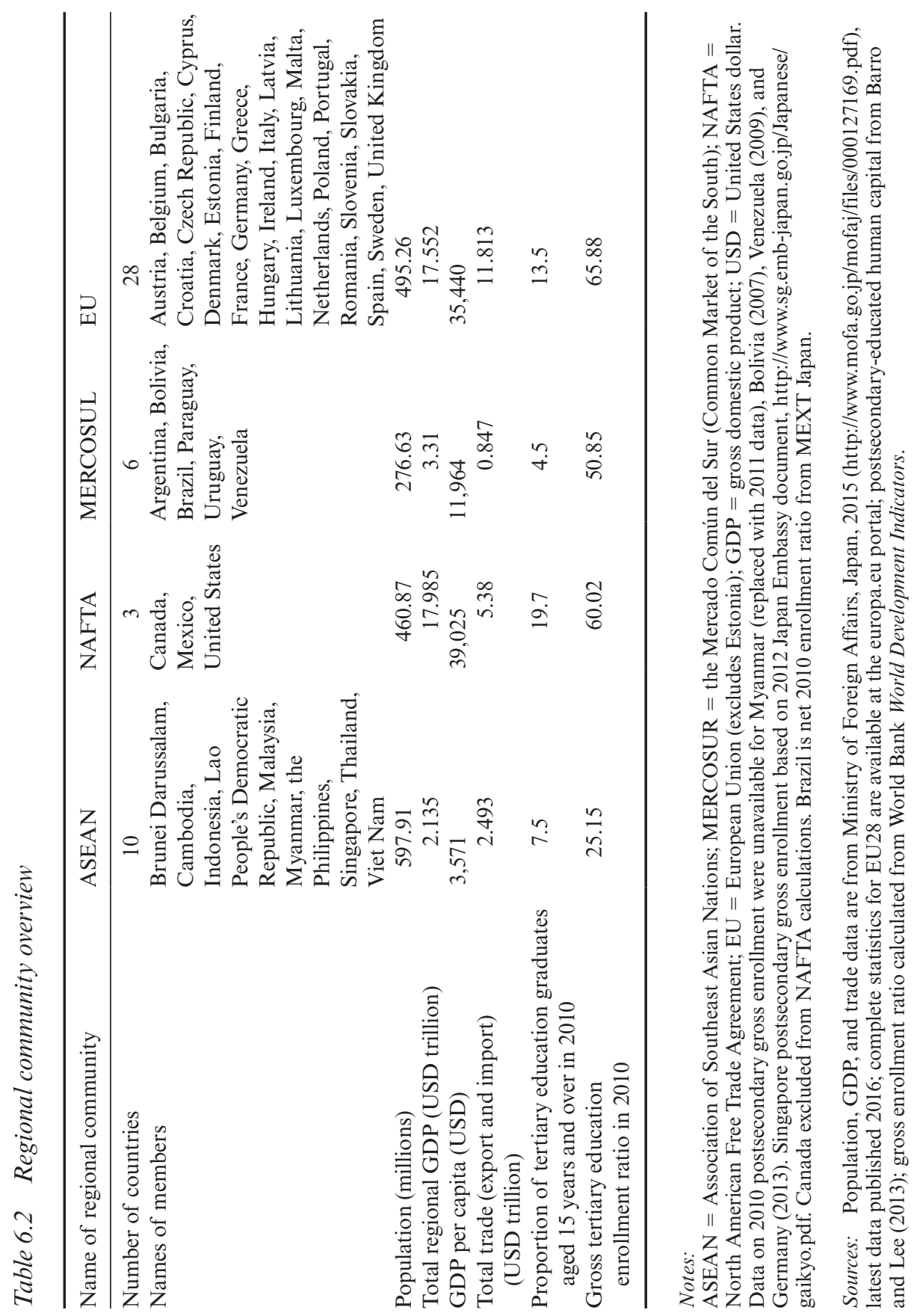




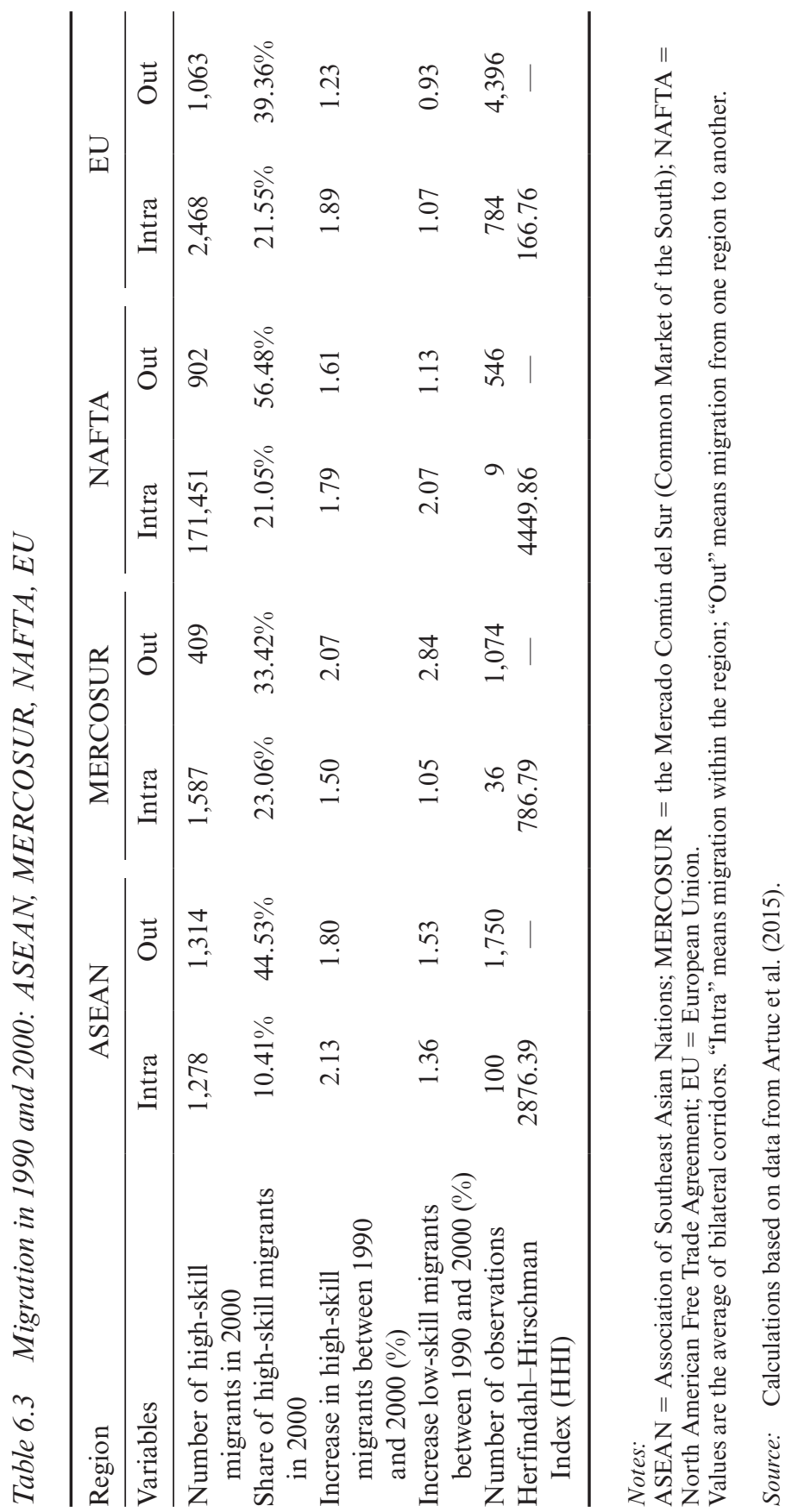


(NAFTA), and 2.32 (EU). Although large intraregional migration within NAFTA and EU members is understandable given host countries are major OECD members - such as the United States in NAFTA countries and the United Kingdom and Germany in the EU-MERCOSUR also had more intraregional high-skill migrants than extra-regional migrants. However, all regional communities had higher proportions of high-skill extra-regional migrants than intraregional migrants. The difference of the proportion between intra- and extra-regional migrant mobility was biggest in ASEAN; the proportion of intra- $(10.41 \%)$ versus extra-regional migrant mobility $(44.53 \%)$ is 4.28 . Among other regions, the highest proportion was 2.68 in NAFTA; the lowest was 1.45 in MERCOSUR.

Between 1990 and 2000 intra-ASEAN high-skill migration showed the highest increase $(213 \%)$, higher than extra-regional migrant mobility $(180 \%)$. The EU and NAFTA also had bigger increases in intraregional migration than extra-regional migration. High-skill migration increases were higher than low-skill migration increases in ASEAN and the EU. High-skill mobility in intraregional migration increased more than highskill extra-regional migrant mobility, except in NAFTA.

In terms of bilateral intraregional migration corridors, the HHI was high in ASEAN $(2,876.39)$ and NAFTA $(4,449.86)$ - both of which are categorized as having high oligopoly tendencies. The HHI was lowest in the EU (166.76), followed by MERCOSUR (786.79), both categorized as having low-level oligopolies with greater competition.

\subsubsection{Corridors of high-skill migration within ASEAN}

Table 6.4a presents the top 10 corridors of intra-ASEAN migration in 1990 and 2000. Total migration more than doubled (118\%) during the period. In both 1990 and 2000, the top 10 corridors covered more than $85 \%$ of total intraregional high-skill migration. The top corridor-from Malaysia to Singapore - more than tripled. In 2000, just over half of the total ASEAN high-skill migration (52\%) was through this corridor, an increase of almost 20\% from 1990. And with ASEAN admitting Viet Nam in 1995, the Lao PDR and Myanmar in 1997, and Cambodia in 1999, new high-skill migration corridors developed over the decade.

Table 6.4b shows the top 10 corridors for ASEAN extra-regional migration in 1990 and 2000. Total extra-regional migration increased $78 \%$ over the period. The top 10 corridors account for some $75 \%$ of the total in both 1990 and 2000. The top seven corridors held the same rank between 1990 and 2000. The US was the most popular host, with others prominent because of their colonial history (Indonesia-the Netherlands), geographical proximity (Australia as host), and migration experience (the Philippines-Saudi Arabia).

Table $6.4 \mathrm{c}$ describes the top 10 corridors of migration into ASEAN in 


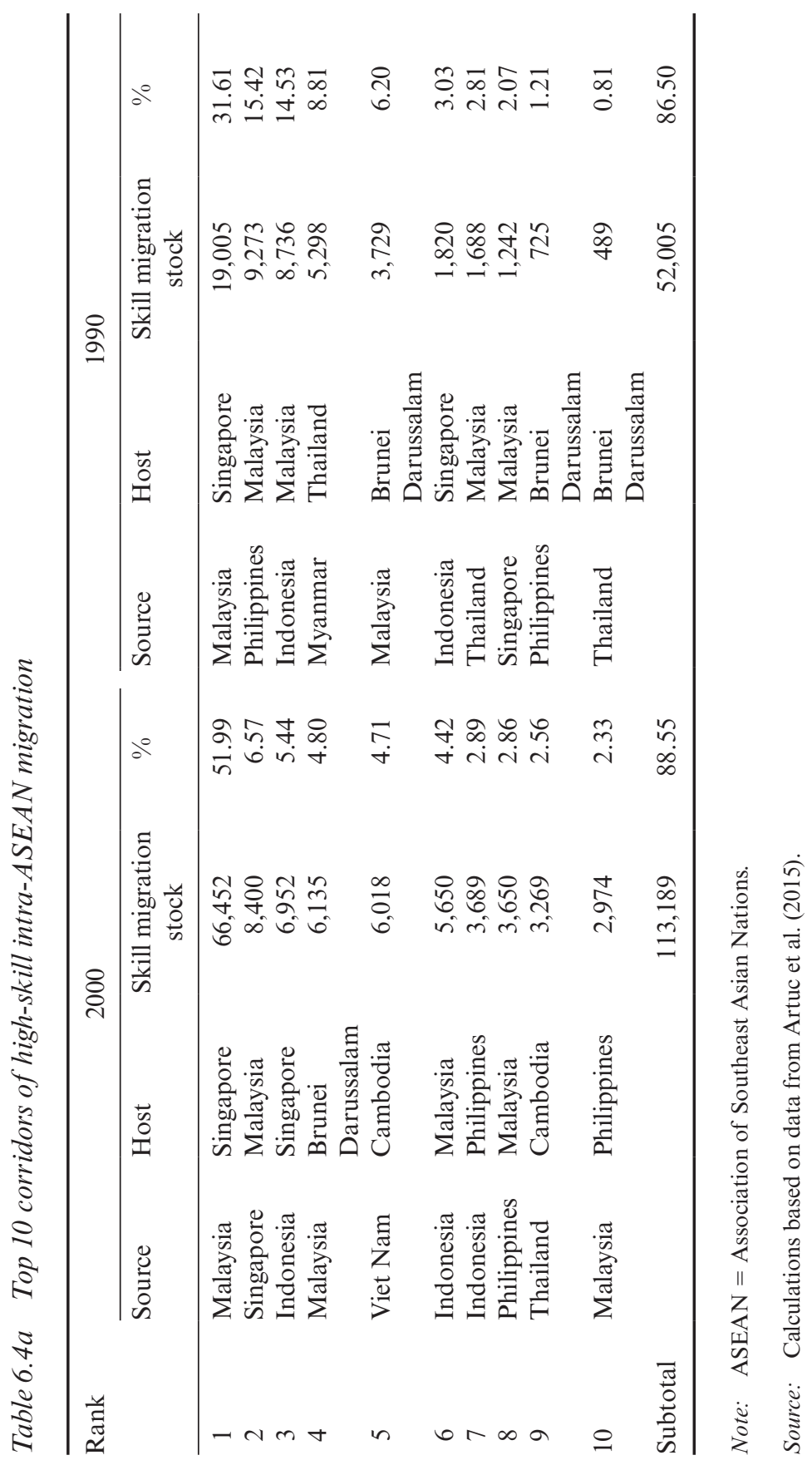




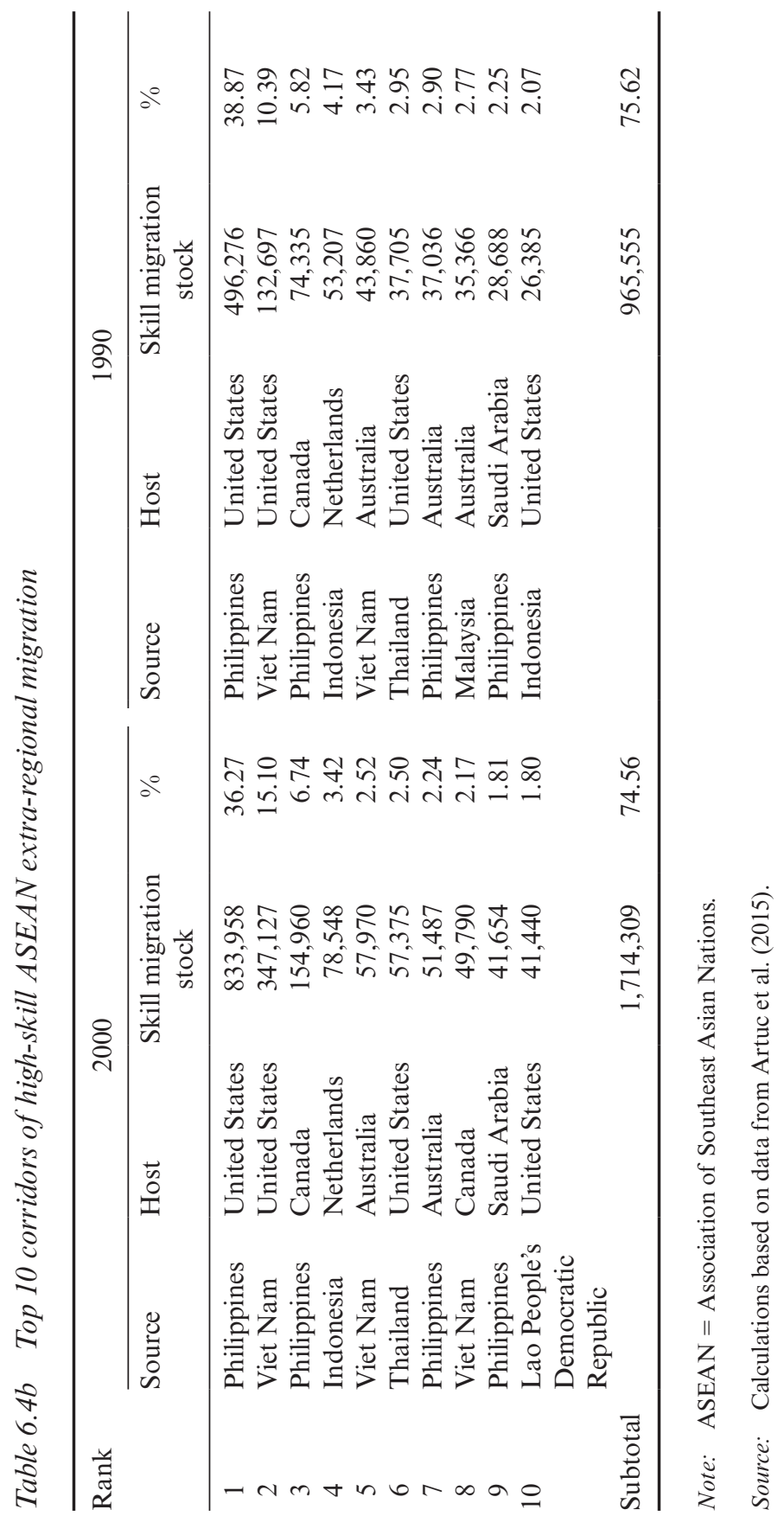




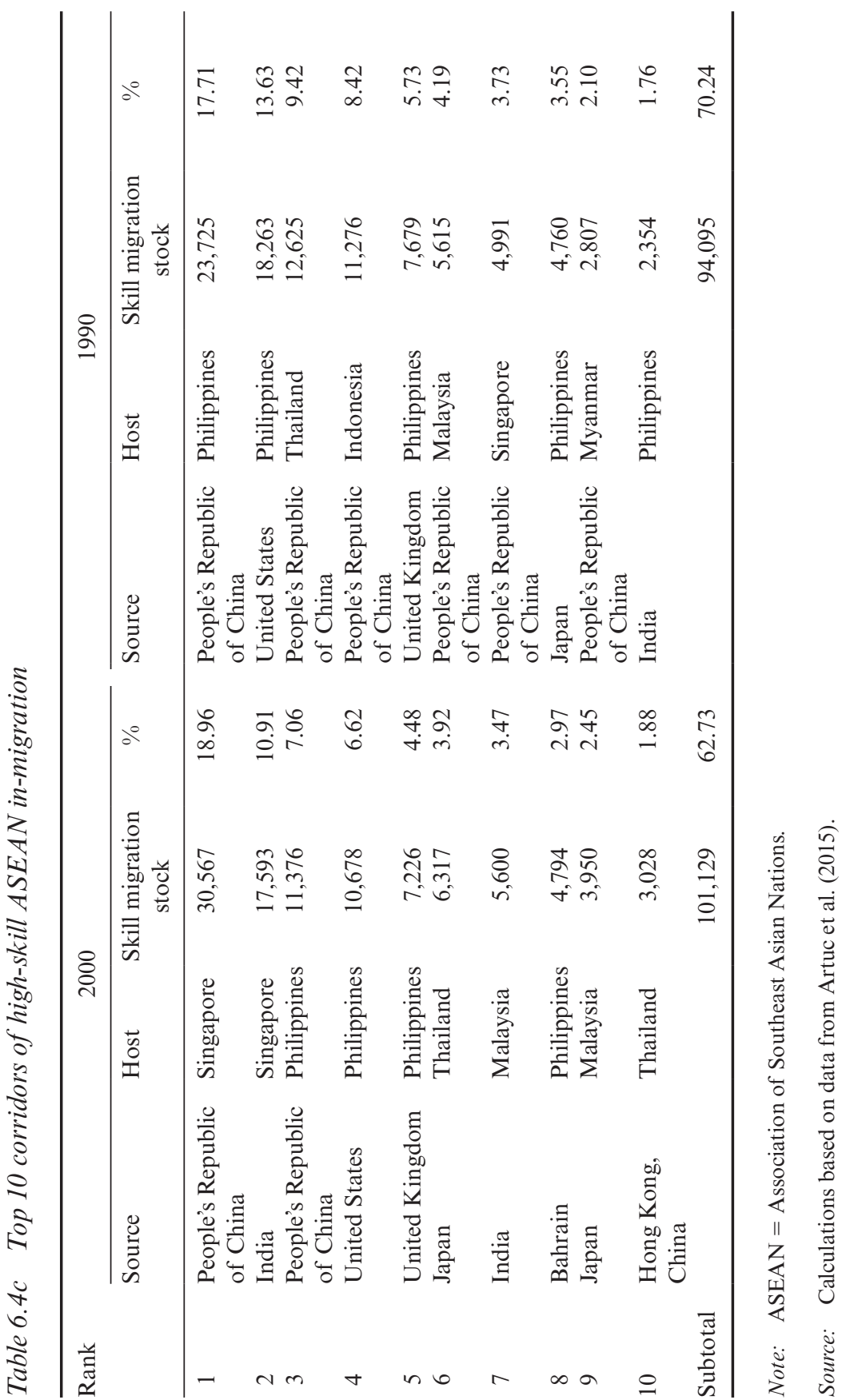


1990 and 2000. The increase was 7\% over the decade, below the growth of both intraregional and extra-regional migration of high-skill migrants. On one hand, the slow growth was because of a decrease in high-skill migration to the Philippines. On the other hand, Singapore became far more attractive as a host for migrants from the People's Republic of China (PRC) and India. In addition, corridors grew more diverse over the period. For example, the PRC as source country appeared six times in 1990 and twice in 2000, while the Philippines as a host country appeared five times in 1990 and three times in 2000.

\subsection{The Relationship between High-Skill Intra-ASEAN Migration and Postsecondary-Educated Human Capital (Research Question 2)}

For Model (6.1), deviance and Pearson goodness-of-fit tests were conducted to decide the count data model distribution (deviance: goodnessof-fit $=9199.468, p>\chi^{2}(7823)=0.0000$; Pearson: goodness-of-fit $=$ $\left.7672.638, p>\chi^{2}(7823)=0.8858\right)$. Although the results of these two tests are inconsistent, the Pearson test supports the use of Poisson distribution. The Vuong test was then conducted, with the results supporting the use of the zero-inflated model $(\mathrm{z}=32.36, \mathrm{p}>\mathrm{z}=0.0000)$. Therefore, the zero-inflated Poisson regression is appropriate for Model (6.1) and the panel data estimation with random effect. The results are in Table 6.5, showing $\mathrm{R}^{2}$ higher in the panel data estimation shown from columns (1) to (8) than the zero-inflated Poisson estimation shown from columns (9) to (16). Although the significance and sign of coefficients are similar between the two estimation types (with some exceptions), the results estimated by panel data is better.

From the estimation results targeting the entire data shown as World in column (1), the coefficient of four regional dummy variables does not show any significant result. However, the cross term of human capital stock in ASEAN countries does show significant results, indicating that the human capital stock in either ASEAN source or host countries has a different relationship with high-skill migration to other regions.

The similarities and differences between ASEAN countries and other regions appear in the relationship between bilateral countries. First, the coefficient of distance variable for intra-ASEAN mobility shown in column (3) is negative and significant, and that of extra-ASEAN migration in column (4) is insignificant - the same tendency as that for the EU. This differs from expectations, which assumes negative and significant coefficients of the distance variable for any migration type. This result means that distance matters for intra-ASEAN and intra-EU migration, but not for extra-regional migration. The coefficient of trade is significant 
and positive for intra-ASEAN mobility in column (3). Trade seems to have little relationship with skill migration within ASEAN countries, which again differs from expectations as well as the results of Jurje and Lavenex (2015). The common official language is also positive and significant for both intra- and extra-ASEAN migration - as with the EU. For source- and host-specific characteristics, the coefficient of income in the host variable has - as expected - positive and significant results for all four regions and the world. Income in source is positive and significant for intra-ASEAN and extra-NAFTA migration, but negative and significant in both intraand extra-EU migrations in columns (7) and (8). Against expectations, human capital in the host variable shows insignificant results. However, the source variable includes various regions and types of migrationthe world, extra-ASEAN migration, intra- and extra-EU migration are positive and significant, while extra-NAFTA migration is negative and significant. Income and human capital stock differences between source and host countries do not show any significant results except for the world estimation - these differences have little influence on intraregional migration, but could have some relationship with income and human capital levels in both source and host countries.

In summary, when migrating within ASEAN, high-skill workers from higher-income countries move to nearby countries with relatively higher incomes and common languages. The migration flow is irrespective of trade in ASEAN countries - which differs from the relationship in MERCOSUR, NAFTA, and the EU.

In Table 6.6, the estimation results for different combinations of independent variables in Model (6.1) — targeting high-skill intra-ASEAN migration-are shown from columns (17) to (22). Results on targeting high-skill intra-EU migration are in columns (23) to (28). The average of $\mathrm{R}^{2}$ is 0.457 in ASEAN countries and 0.702 in the EU, which indicates that the current education and economy-focused model had a better fit for the EU-although the number of observations between the two datasets is on average 72 and 694, respectively. Here, the results of distance and official language have the same sign and significance as all the results. The coefficient of the income difference variable does not show any significant result, but that of the human capital difference is significant for the model without source- and host-specific variables. Human capital in the host variable shows an insignificant result in column (23), and that of host shows positive and significant results at the $1 \%$ level in column (21). These results indicate that high-skill migration has a positive relationship with human capital in the source country, but not the host country within ASEAN and the EU. The coefficient of income level in either source or host country is also significant. 


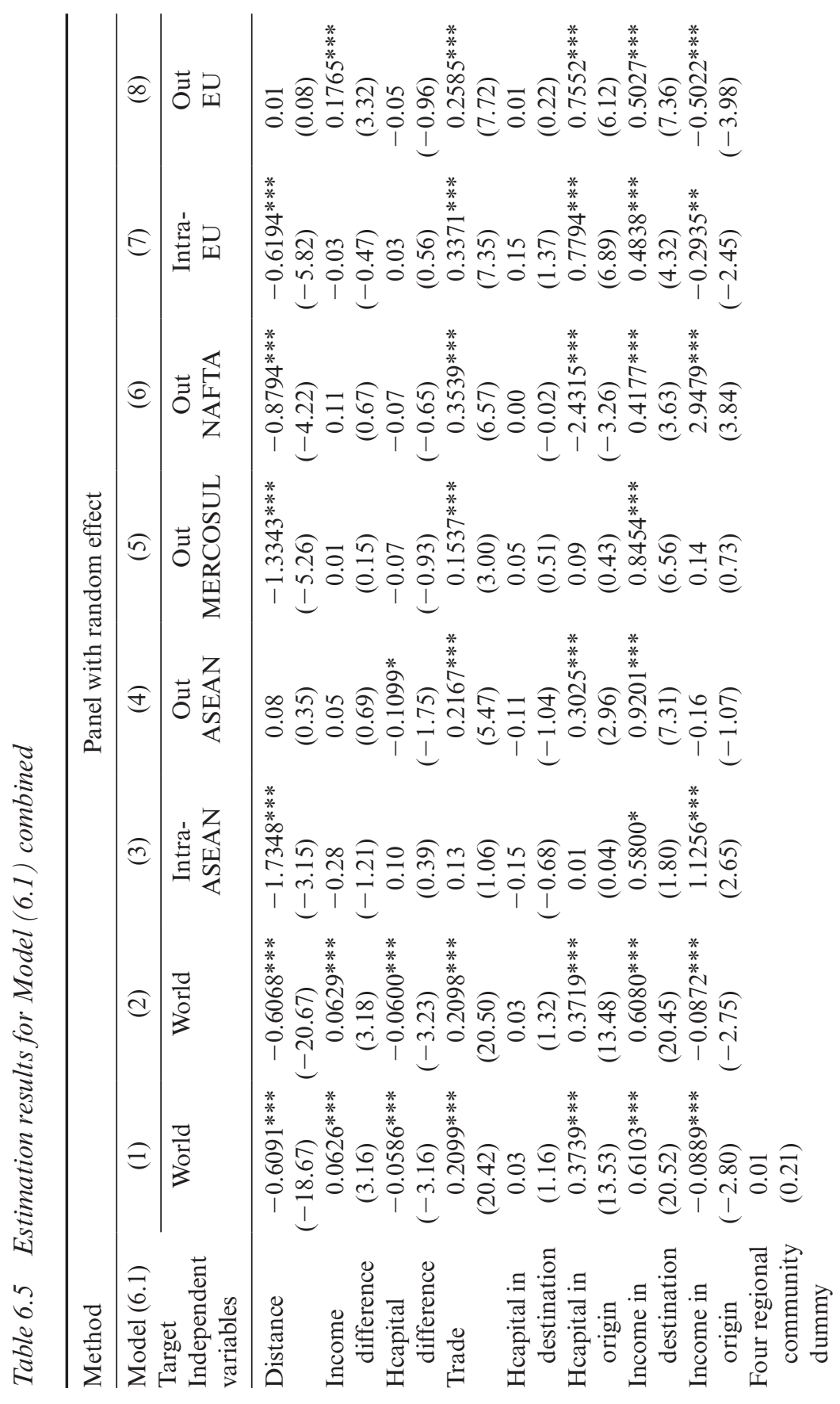




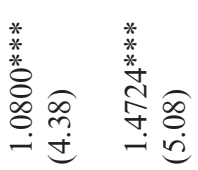

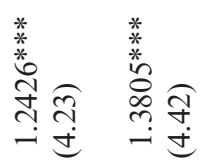

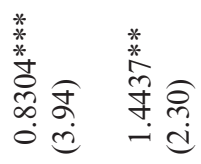

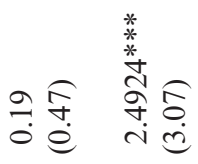

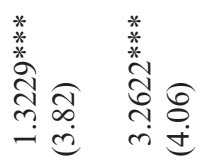

$\overbrace{\text { ñ ก } ~}^{*}$ ก

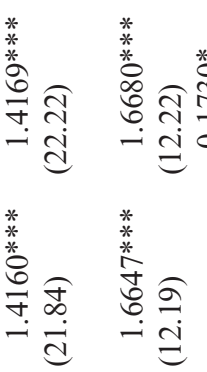

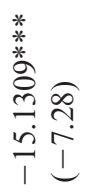

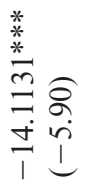

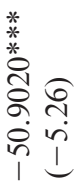

䓠

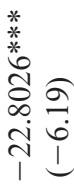

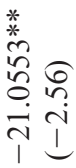

$*$
$*$
$*$
6
0
$\infty$
$\dot{0} 0$
$\dot{1}$
1

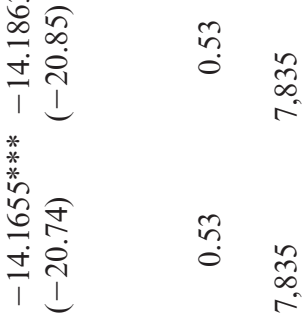

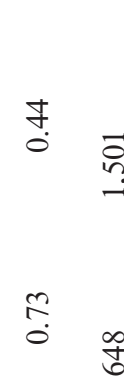

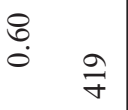

$\stackrel{\varpi}{\circ}$

$\stackrel{n}{n} \frac{N}{n}$

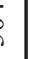

$\mid$

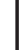

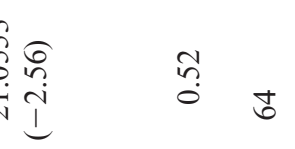

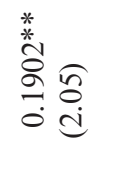

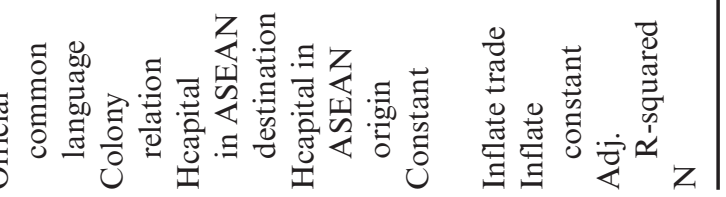

183 


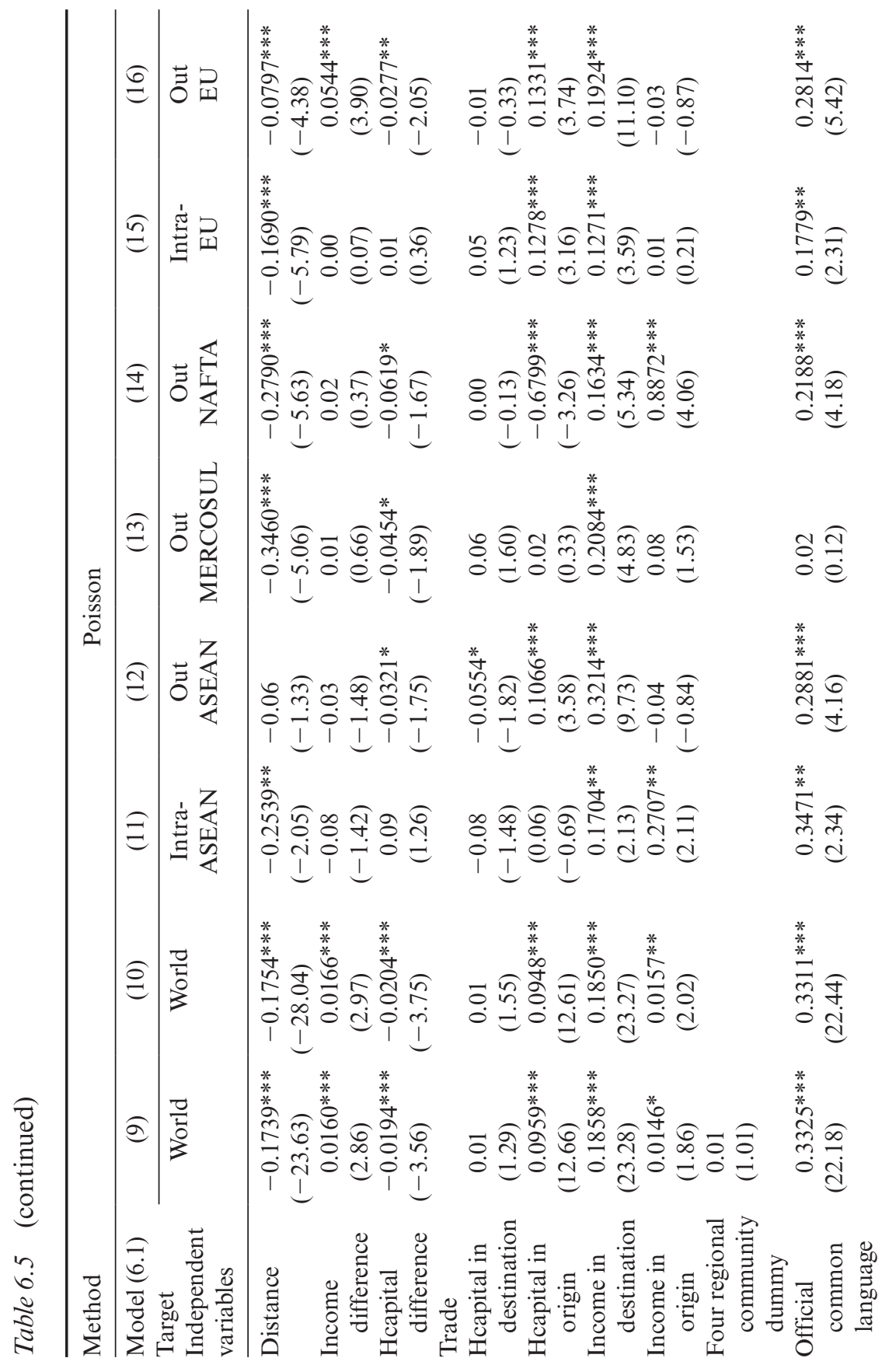




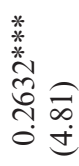

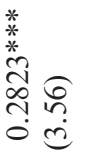

๖:

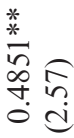

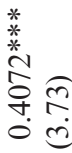

$\stackrel{8}{\circ} \odot$

$\stackrel{*}{*}$

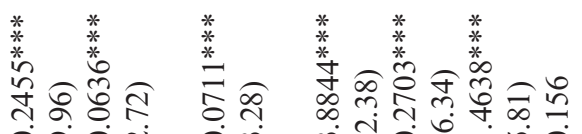

व்

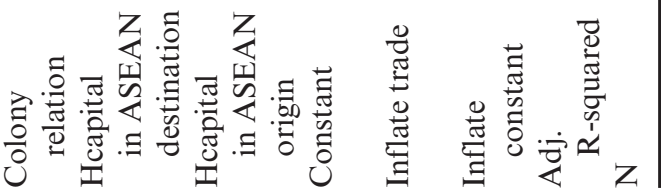

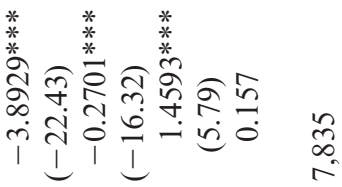

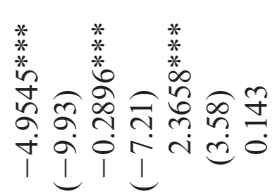

$\stackrel{*}{*}$

ำ 증ำ

$\dot{i}+\dot{i} \dot{i} \infty \dot{0}$

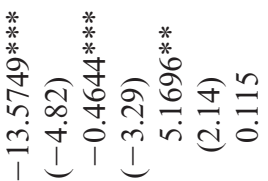

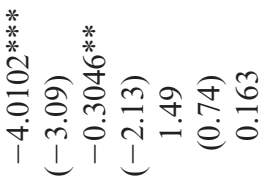

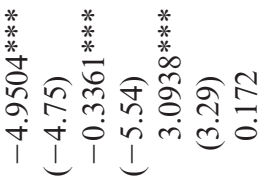

$\stackrel{*}{N}$

สิซฒ

i I

オ

กิ

in

$\frac{\vartheta}{\gamma}$

ঠ

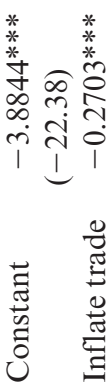

乐

욤

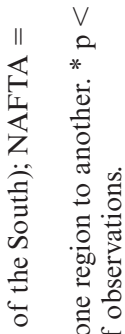

피

芯这苛

苛

ป

范

क

ฮ

ठี่

० क्ष

导 至

$\sum^{\infty} \Xi 0$

․ㄹㄹ

․ㅡㄴ

当

ᄋํํㄹ

, w

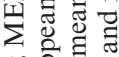

in 을 을

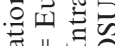

乙一⿻

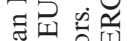

要语事文

เ

ङ

要这

क 웅

语

官。

数歌 㐘

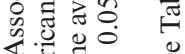

II

乙娄芯

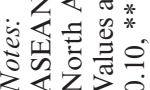




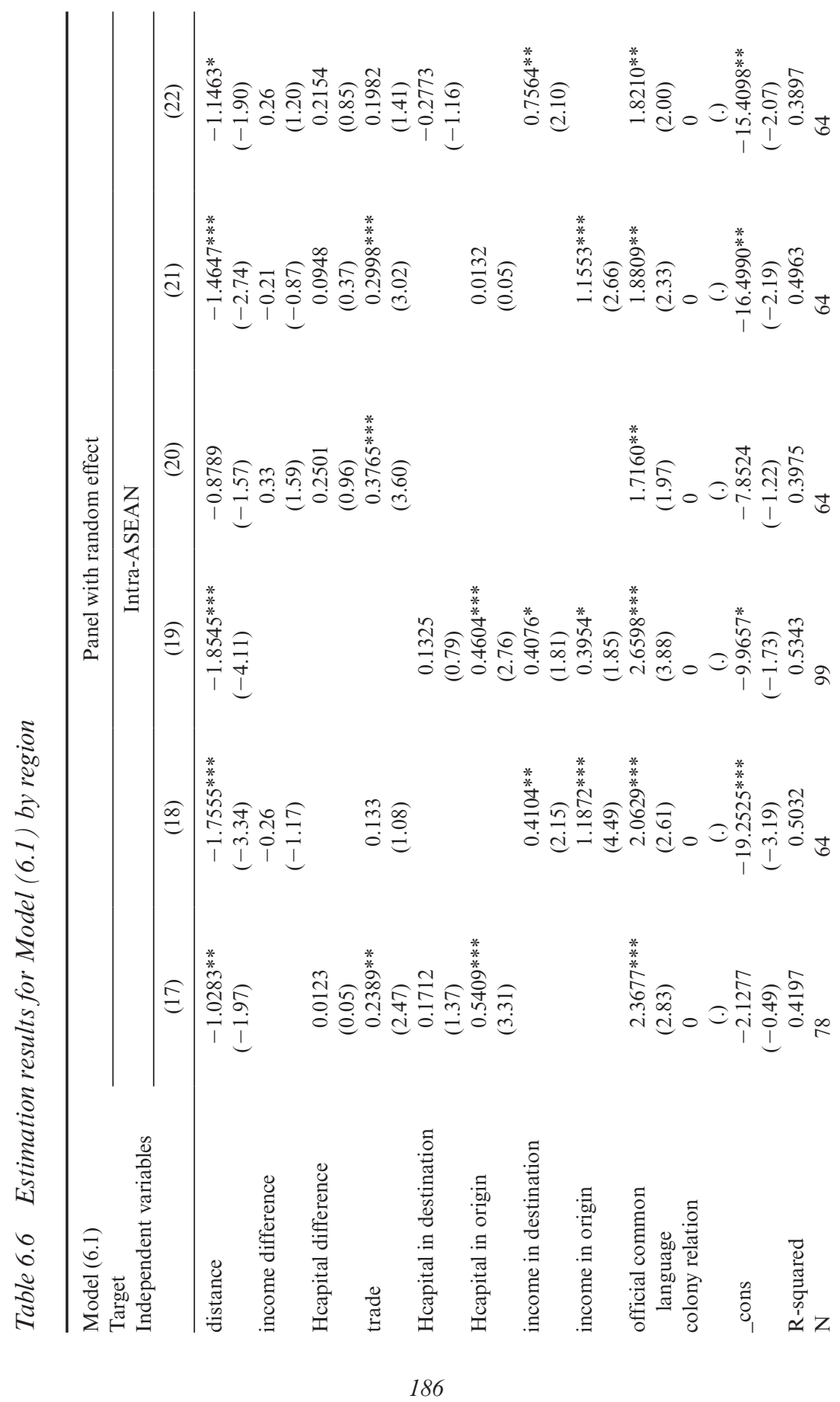




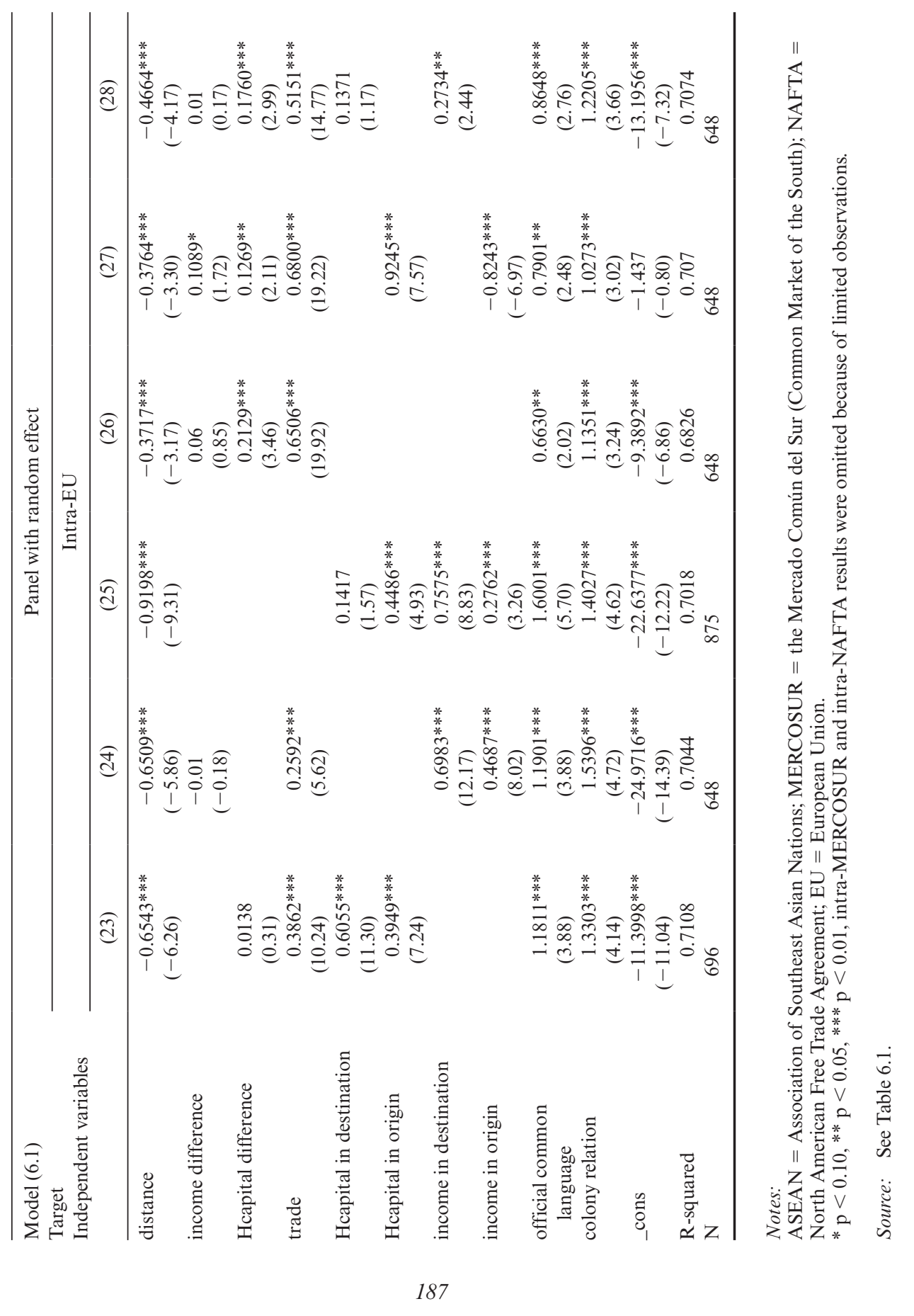




\subsection{How High-Skill Intra-ASEAN Migration Influences Postsecondary Education Enrollment (Research Question 3)}

Model (6.2) was estimated using the ordinary least squares method (Table 6.7). The adjusted $\mathrm{R}^{2}$ is low, which suggests the need to either include additional independent variables or modify the model or estimation method. All results show the coefficients of high-skill migration variables are positive and significant at $1 \%$. This was expected. The change in high-skill migration has a positive relationship with the change in human capital stock, which indicates the probability that inter-country migration drives the accumulation of human stock in both source and host countries. The coefficient of the income change variable is insignificant except for the world, which is positive and significant, and extra-ASEAN and intra-EU migration, which are negative and significant. This was unexpected. One interpretation is that it results from economic stagnation and an increase in postsecondary education enrollment in host countries - such as in Japan recently. But this needs to be confirmed.

\section{CONCLUSIONS}

This chapter clarifies two main points to the literature on high-skill migration within ASEAN. It clarifies the nature of high-skill migration and the relationship between high-skill migration and postsecondary education. The analysis is based on the latest available dataset from 1990 and 2000 provided by Artuc et al. (2015).

First, intra-ASEAN migration was responsible for the lowest proportion of high-skill migration and the second-highest concentration of bilateral corridors among four regional communities-ASEAN, MERCOSUR, NAFTA, and the EU. The findings clarify migration characteristics as indicated by previous studies. In both 1990 and 2000, the concentration of migrants in the top 10 bilateral corridors accounted for more than $85 \%$ of the intraregional high-skill migration. In 2000, just over half of total migration flowed from Malaysia to Singapore, up from less than one-third in 1990. Also, there was a modest increase of immigrants into ASEAN countries, but the number of high-skill migrants leaving ASEAN and intra-ASEAN migration nearly doubled.

Second, the results indicate that human capital stock in source countries - not in host countries - may explain high-skill intra-ASEAN migration. However, bilateral high-skill intra-ASEAN mobility explains postsecondary-educated human capital stock in both source and host countries; therefore, high-skill ASEAN mobility could have a positive 


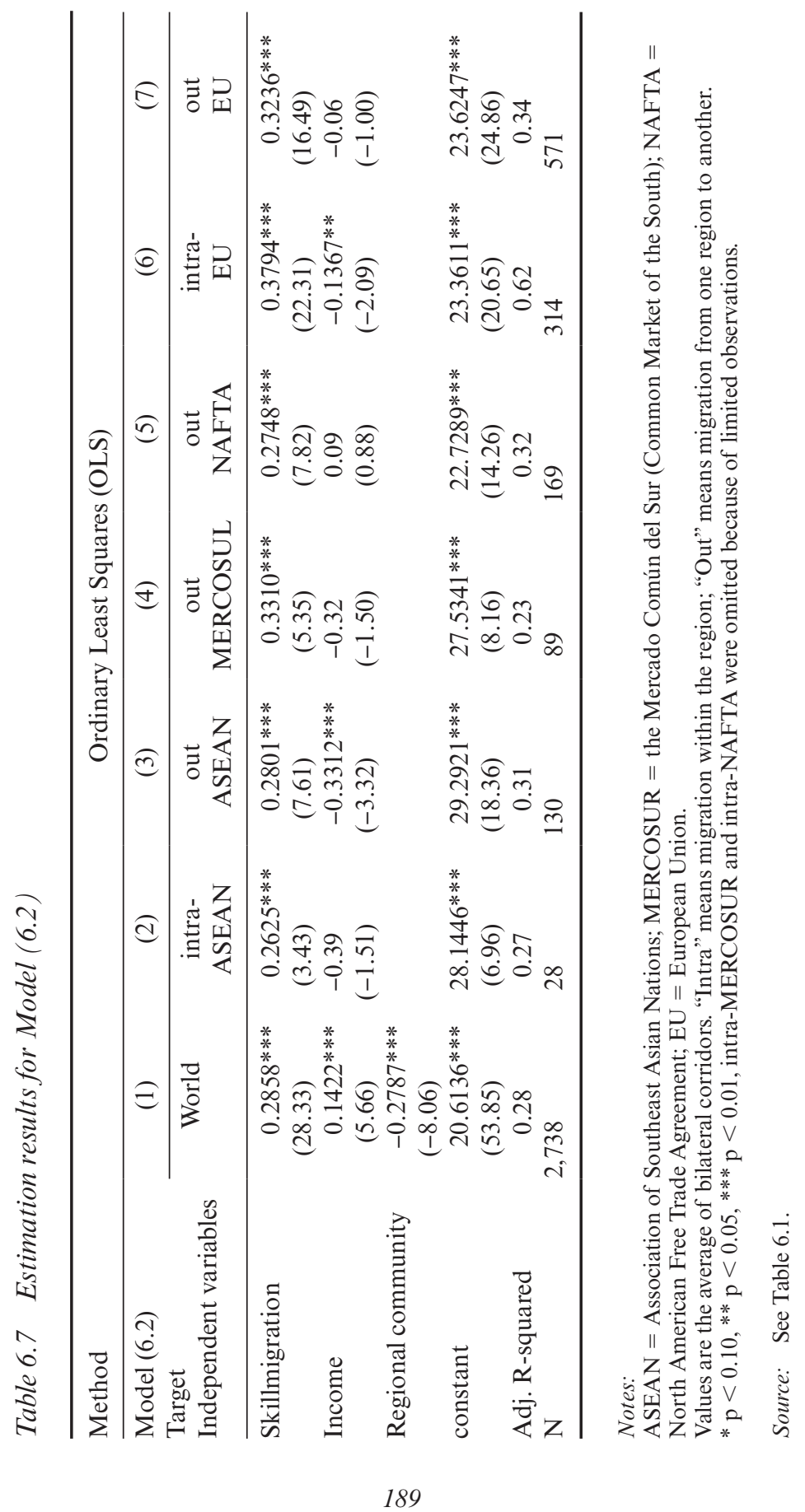


two-way relationship with greater investment in postsecondary education in source countries.

There are several policy implications. First, there are reasons to encourage high-skill intra-ASEAN migration: (i) it tends to increase postsecondary education enrollment in source countries - given the low level of current high-skill intra-ASEAN mobility compared with MERCOSUR, NAFTA, and the EU. Therefore, high-skill intra-ASEAN migration benefited the accumulation of human capital from 1990 to 2000 throughout the region, compared with the three other regions. It makes sense to discuss migration and postsecondary education policies together.

Second, high-skill migration into ASEAN should be investigated further as there was only a modest increase compared with both intraASEAN and extra-regional migration. This goes beyond the AEC's focus on intra-ASEAN migration. However, high-skill migration to ASEAN relates directly to its competitiveness - and could relate to intra-ASEAN migration as it picks up. Trends have likely changed since 2000. Longer time series data would make analysis available for causality relationships between regional high-skill migration and postsecondary-educated human capital accumulation. Also, international study makes a difference. The rise in international study is an important driver for high-skill migration in Asia (ADBI 2014) and could be for ASEAN in particular.

\section{NOTES}

1. This is understandable as the policy and research debate on migration and development has swung back and forth like a pendulum (de Haas 2012).

2. The HHI is calculated as HHI $=s 1^{2}+s 2^{2}+s 3^{2}+\ldots+s^{2}$ (where sn is the market share of the $\mathrm{i}^{\text {th }}$ firm). If the firm has $100 \%$ market share, HHI equals $10,000\left(100^{2}\right)$, indicating a monopoly.

\section{REFERENCES}

Artuc, E., F. Docquier, Ç. Özden, and C. Parsons (2015), 'A Global Assessment of Human Capital Mobility: The Role of Non-OECD Hosts', World Development 65: 6-26. doi:10.1016/j.worlddev.2014.04.004.

Asian Development Bank Institute (2014), Labor Migration, Skills, and Student Mobility in Asia, http://hdl.handle.net/11540/174.

Batista, C., A. Lacuesta, and P.C. Vicente (2012), 'Testing the "Brain Gain" Hypothesis: Micro Evidence from Cape Verde', Journal of Development Economics 97 (1): 32-45. doi:10.1016/j.jdeveco.2011.01.005.

Beine, M., F. Docquier, and Ç. Özden (2010), 'On the Robustness of Brain Gain Estimates', Annales d'Economie et de Statistique 97: 143-66. 
Beine, M., F. Docquier, and H. Rapoport (2001), 'Brain Drain and Economic Growth: Theory and Evidence', Journal of Development Economics 64 (1): 275-89. doi:10.1016/S0304-3878(00)00133-4.

Beine, M., F. Docquier, and H. Rapoport (2007), 'Measuring International Skilled Migration: A New Database Controlling for Age of Entry', The World Bank Economic Review 21 (2): 249-54. doi:10.1093/wber/lhm007.

Beine, M., F. Docquier, and H. Rapoport (2008), 'Brain Drain and Human Capital Formation in Developing Countries: Winners and Losers', The Economic Journal 118 (528): 631-52. doi:10.1111/j.1468-0297.2008.02135.x.

Beine, M., R. Noël, and L. Ragot (2014), 'Determinants of the International Mobility of Students', Economics of Education Review 41: 40-54. doi:10.1016/j. econedurev.2014.03.003.

Bhagwati, J. (2009), 'Overview of Issues'. In Skilled Immigration Today: Prospects, Problems, and Policies, Jagdish Bhagwati and Gordon H Hanson (eds), 3-11. Oxford: Oxford University Press.

Borjas, G.J. (1994), 'Long-Run Convergence of Ethnic Skill Differentials: The Children and Grandchildren of the Great Migration', Industrial \& Labor Relations Review 47 (4): 553-73. doi:10.1177/001979399404700403.

Cervantes, M. and D. Guellec (2002), 'The Brain Drain: Old Myths, New Realities', OECD Observer 230. http://www.oecdobserver.org/news/archivestory. php/aid/673/The_brain_drain:_Old_myths,_new_realities.html.

Checchi, D., G. De Simone, and R. Faini (2007), 'Skilled Migration, FDI and Human Capital Investment', IZA Discussion Paper No. 2795. https://pdfs. semanticscholar.org/e63f/c6ece4db8bd0a19483130e0195d556f28edc.pdf.

Clark, X., T.J. Hatton, and J.G. Williamson (2007), 'Explaining US Immigration, 1971-1998', Review of Economics and Statistics 89 (2): 359-73.

Clemens, M.A., Ç. Özden, and H. Rapoport (2014), 'Migration and Development Research is Moving Far Beyond Remittances', World Development 64: 121-4. doi:10.1016/j.worlddev.2014.05.018.

de Haas, H. (2009), 'Mobility and Human Development', Human Development Research Papers 2009/01, New York: UNDP. https://heindehaas.files.wordpress. com/2015/05/2009-undp-mobility-and-human-development.pdf.

de Haas, H. (2010), 'Migration and Development: A Theoretical Perspective', International Migration Review 44 (1): 227-64. doi:10.1111/j.1747-7379.2009 .00804.x.

de Haas, H. (2012), 'The Migration and Development Pendulum: A Critical View on Research and Policy', International Migration 50 (3): 8-25. doi:10.11 11/j.1468-2435.2012.00755.x.

Docquier, F. and A. Marfouk (2004), 'Measuring the International Mobility of Skilled Workers (1990-2000): Release 1.0', Policy research working papers 3381, World Bank, Development Research Group, Trade Team. doi:10.1596/1813-9450-3381.

Docquier, F. and A. Marfouk (2006), 'International Migration by Education Attainment, 1990-2000'. In International Migration, Remittances and the Brain Drain, Çağlar Özden and Maurice Schiff (eds), 151-200. New York: Palgrave Macmillan.

Docquier, F. and H. Rapoport (2012), 'Globalization, Brain Drain, and Development', Journal of Economic Literature 50 (3): 681-730. doi:10.1257/jel.50.3.681.

Dustmann, C. and A. Glitz (2011), Migration and Education, 4: 327-439. doi:10.1016/b978-0-444-53444-6.00004-3.

Easterly, W. and Y. Nyarko (2009), 'Is the Brain Drain Good for Africa? In Skilled 
Immigration Today: Prospects, Problems, and Policies, Jagdish Bhagwati and Gordon H. Hanson (eds), 316-61. Oxford: Oxford University Press.

Eccles, Jacquelynne S. (1994), 'Understanding Women's Educational and Occupational Choices: Applying the Eccles et al. Model of Achievement-Related Choices', Psychology of Women Quarterly 18 (4): 585-609. doi:10.1111/j.14716402.1994.tb01049.x.

Eccles, Jacquelynne S. (2005), 'Studying Gender and Ethnic Differences in Participation in Math, Physical Science, and Information Technology', New Directions for Child and Adolescent Development 110: 7-14. doi:10.1002/cd.146.

Faist, T. (1997), 'The Crucial Meso-Level'. In International Migration, Immobility and Development: Multidisciplinary Perspectives, Tomas Hammar, Grete Brochmann, Kristof Tamas, and Thomas Faist (eds), 187-217. Oxford: Berg.

Gibson, J. and D. McKenzie (2011), 'The Microeconomic Determinants of Emigration and Return Migration of the Best and Brightest: Evidence from the Pacific', Journal of Development Economics 95 (1): 18-29. doi:10.1016/j.jdeveco.2009.11.002.

Grogger, J. and G.H. Hanson (2011), 'Income Maximization and the Selection and Sorting of International Migrants', Journal of Development Economics 95 (1): 42-57. doi:10.1016/j.jdeveco.2010.06.003.

Jurje, F. and S. Lavenex (2015), 'ASEAN Economic Community: What Model for Labour Mobility?' NCCR Trade Working Paper No. 2015/02 January 2015. http:// www.nccr-trade.org/fileadmin/user_upload/nccr-trade.ch/wp4/NCCR_working Paper_ASEAN_Jurje_Lavenex_.pdf.

Kato, M. (2016), 'Regional Differences in the University Advancement Ratio for Women in Contemporary Japan', Paper presented at the 55th annual meeting of the Western Regional Science Association, Hawaii.

Kato, M. and A. Ando (2007), 'Causality Analysis between Human Capital Accumulation and Economic Development with Lags', Journal of Applied Regional Science 12: 1-13.

Kim, K. and J.E. Cohen (2010), 'Determinants of International Migration Flows to and from Industrialized Countries: A Panel Data Approach Beyond Gravity', International Migration Review 44 (4): 899-932.

King, R. (2012), 'Theories and Typologies of Migration: An Overview and a Primer', Willy Brandt Series of Working Papers in International Migration and Ethnic Relations, 3/12.

Lucas, R.E. (1988), 'On the Mechanics of Economic Development', Journal of Monetary Economics 22 (1): 3-42. doi:10.1016/0304-3932(88)90168-7.

Lucas, R.E. (2007), 'International Migration and Economic Development in Low-Income Countries: Lessons from Recent Data'. In Immigrants and Their International Money Flows, Susan Pozo (ed.), 11-32. Kalamazoo, MI: W.E. Upjohn Institute for Employment Research.

Maggioni, M.A. and T.E. Uberti (2009), 'Knowledge Networks Across Europe: Which Distance Matters?' Annals of Regional Science 43 (3): 691-720. doi:10.1007/s00168-008-0254-7.

Martin, P.L. (1996), 'The Anatomy of a Migration Hump'. In Development Strategy, Employment, and Migration: Insights from Models, Edward J. Taylor (ed.), 43-62. Paris: OECD Development Centre.

Mayda, A.M. (2010), 'International Migration: A Panel Data Analysis of the Determinants of Bilateral Flows', Journal of Population Economics 23(4): 1249-74.

Moretti, E. (2013), The New Geography of Jobs. Boston: Houghton Mifflin Harcourt. 
Mountford, A. (1997), 'Can a Brain Drain Be Good for Growth in the Source Economy?' Journal of Development Economics 53 (2): 287-303. doi:10.1016/ S0304-3878(97)00021-7.

Orbeta, A.C. Jr. (2013), 'Enhancing Labor Mobility in ASEAN: Focus on Lower-skilled Workers', Discussion Paper, Philippine Institute for Development Studies, DP2013-17.

Özden, Ç., C.R. Parsons, M. Schiff, and T.L. Walmsley (2011), 'Where on Earth is Everybody?' World Bank Economic Review 25 (1): 12-56. doi:10.1093/wber/ lhr024.

Papademetriou, D., G. Sugiyarto, D.R. Mendoza, and B. Salant (2016), 'Achieving Skill Mobility in the ASEAN Economic Community: Challenges, Opportunities, and Policy Implications'. http://www.adb.org/publications/achieving-skill-mobility -asean-economic-community.

Piore, M.J. (1979), Birds of Passage: Migrant Labour and Industrial Societies. New York: Cambridge University Press.

Ramos, R. (2016), Gravity Models: A Tool for Migration Analysis, IZA World of Labor, 239. doi:10.15185/izawol.239.

Rapoport, H. and F. Docquier (2006), 'The Economics of Migrants' Remittances'. In Handbook of the Economics of Giving, Altruism and Reciprocity, Bruce L. Gardner and Gordon C. Rausser (eds), 1135-1200. North Holland: Elsevier.

Schiff, M. (2005), 'Brain Gain: Claims about Its Size and Impact on Welfare and Growth Are Greatly Exaggerated'. In International Migration, Remittances and the Brain Drain, Çağlar Özden and Maurice Schiff (eds). Washington, DC: World Bank and Palgrave Macmillan.

Sen, A.K. (1999), Development as Freedom. New York: Anchor Books.

Stark, O., C. Helmenstein, and A. Prskawetz (1997), 'A Brain Gain with a Brain Drain', Economics Letters 55 (2): 227-34. doi:10.1016/S0165-1765(97)00085-2.

Sugiyarto, G. and D.R. Agunias (2014), 'A "Freer" Flow of Skilled Labour within ASEAN: Aspirations, Opportunities, and Challenges in 2015 and Beyond', Migration Policy Institute. http://www.migrationpolicy.org/research/freer-flowskilled-labour-within-asean-aspirations-opportunities-and-challenges- 2015.

Wozniak, A. (2010), 'Are College Graduates More Responsive to Distant Labor Market Opportunities?' Journal of Human Resources 45 (4): 944-70. doi:10.3368/ jhr.45.4.944.

Yang, D. (2008), 'International Migration, Remittances and Household Investment: Evidence from Philippine Migrants' Exchange Rate Shocks', The Economic Journal 118 (528): 591-630. doi:10.1111/j.1468-0297.2008.02134.x. 